UDC 614.7

\title{
HYGIENIC ANALYSIS OF SOCIAL AND SANITARY-EPIDEMIOLOGICAL LIVING CONDITIONS OF THE POPULATION OF THE ALTAI TERRITORY
}

\author{
${ }^{1}$ A.A. Ushakov, ${ }^{2}$ V.V. Turbinskiy, ${ }^{1}$ A.S. Katunina \\ ${ }^{1}$ Administration of the Federal Service for Surveillance on Consumer Rights Protection \\ and Human Wellbeing in the Altai Territory, Russian Federation, Altai Territory, Barnaul, \\ 28 M. Gorkogo St., 656056 \\ ${ }^{2}$ FBIS “Novosibirsk Research Institute of Hygiene” of Rospotrebnadzor, \\ Russian Federation, Novosibirsk, 7 Parkhomenko St., 630108
}

Materials on the health status, social and economic as well as sanitary and hygienic conditions of living of the population of the Altai Territory were analyzed. The comparative analysis of living conditions and health indicators of urban and rural population was conducted. The correlation of health indicators of babies from 0 to 1 year old, children from 0 to 14 years old, adolescents from 15 to 17 years old and adults over 18 years old in dependence on the type of a settlement (urban or rural) with the indices of social, sanitary and hygienic factors of the environment was assessed. Regression equations for health indicators of the population of different age groups from the level of hygienic and social environmental factors were calculated, their regional critical (reference) values were validated. The hygienic assessment of the impact of adverse social, sanitary and hygiene factors of the environment on the health of the Altai Territory population was given.

Key words: health status, social and economic, sanitary and hygienic conditions of living, comparative analysis, assessment of the correlation of health indicators, urban, rural settlements, regression equations, regional critical (reference) values, hygienic assessment.

The concept of development of the Russian Federation and its regions is based on the idea of dynamic and balanced development of economic activity together with natural factors and demographic situation. The efficiency of implementation of separate measures in the certain regions depends on the initial conditions of their social and economic development $[2,3,5]$. The social and sanitary-epidemiological living environment of population is differentiated not only at the macro but also the micro level - in relation to the separate settlements and local administrative and territorial systems. The Altai territory belongs to the agricultural and industrial regions of Russia with deformed economic structure [4]. The change of production priorities occurred in new conditions of market economy. The economic problems affected all the spheres of social life, measures on provision of sanitary and epidemiological well-being and social protection of population - unemployment, fall of living standards, increase of the natural decline in the population, increase of the amount of crimes, deterioration of the food products quality, etc. [2, $3,5]$. To overcome these negative social and sanitary-epidemiological consequences it is necessary to have the targeted, coordinated and systemic measures based on the objective data on the occurring social phenomena $[1,6,7]$.
The study was aimed at the hygienic analysis of the social and sanitary-hygienic living environment factors for the population of the territory and justification of priority factors of risk to the health of population.

Goals of study: characterization of the health condition indicators, social-economic and sanitaryhygienic living conditions for the population of the territory; comparative analysis of the living conditions and health indicators for population of the urban and rural settlements; assessment of the health indicators correlation for children of the age group 0.1 year, 0.14 years, teenagers in the age of 15-47 years and adult population older than 18 years depending on the type of population cluster (urban or rural) with the indicators of social and sanitary-hygienic environmental factors; establishment of regression for the health indicators of population in the different age groups from the level of hygienic and social living environment factors; hygienic assessment of social and sanitaryhygienic living environment factors at the territory.

Materials and methods. The objects of study were 60 rural and 10 urban municipal structures of the territory characterized by the indicators of the social and economic development, level of social health, healthcare system, social conditions of life support, hygienic condition of

(C) Ushakov A.A., Turbinskiy V.V., Katunina A.S., 2015

Ushakov Aleksandr Anatolievich - head of the department of social an hygienic monitoring, Candidate of Medical Science (e-mail: Ushakov AA@22.rospotrebnadzor.ru; tel.: 8 961-979-44-87).

Turbinskiy Viktor Vladislavovich - Director, MD (e-mail: ngi@niig.su; tel.: 838334334 01).

Katunina Anna Sergeevna - chief specialist-expert of the department of social an hygienic monitoring (e-mail: osgm@22.rospotrebnadzor.ru; tel.: 7 (3852) 24-84-88,). 
living environment (atmospheric air, drinking water, food products), natural and climatic conditions. The data of the federal and regional information fund of social and hygienic monitoring (FIF SGM, RIF SGM) on the hygienic factors of living environment at the territory and official data of the plans of social and economic development of cities and districts of the territory were used as the materials of studies. The analysis of data was performed using the hygienic and statistical methods. The mean values comparison method, correlation coefficient and linear regression calculation was used to assess the differences between the objects of study. The statistical processing of data was performed using the computer programs "Statistics 6.0" and Excel applications.

Results and their discussion. The differences between the social living conditions in the urban and rural settlements at the territory are expressed in the differences of social and age structure of their inhabitants. The share of children of the age group 0-14 years in the urban settlements is $15 \%$ of the total number, and in the rural settlements $-18 \%$. In the cities the adult population of the age group older than 18 years is represented by the economically active share which by 1.5 times exceeds the percent of adult working population of rural settlements. The birth-rate between the rural and urban inhabitants does not differ (13.5 per 1000 inhabitants in the city and 13.9 in village, $p=0.402$ ). Therefore, the bigger share of children population in villages is stipulated not by the higher reproduction of young generation but by more intense decline in the elderly population (total mortality of rural and urban population is 16.24 and 14.19 cases per 1000 of population, respectively $(p=0.002)$.

The indicators of the social and economic development of the rural and urban settlements of the territory are characterized by the apparent differences in the level of investment to the fixed capital per capita (in the urban -30.9 thous. rub., 17.3 thous. rub. - in the rural), level of the average per capita income of population (in the urban - 18.4 thous. rub., 13.9 thous. rub. - in the rural), number of doctors (709.3 and 38.6, respectively) and nursing staff (1 543.1 and 144.3, respectively). At the same time the expenses for education of one student in the rural settlements exceed such expenses in the urban settlements (12 631.2 and 10457.2 rub., respectively).

The urban settlements, compared to the rural, have less by $10 \%$ of living space per 1 person $\left(22.4 \pm 0.72 \mathrm{~m}^{2}\right.$, at $24.59 \pm 0.35 \mathrm{~m}^{2}$ in the country, $p<0.05)$, less by 2 times of apartments without water supply $(18.2 \pm 3.9 \%$, at $36.86 \pm 2.76$ in the country, $p<0.05)$ and by $42 \%$ of apartments without sewage system $(31.1 \pm 5.01$ and $54.31 \pm 2.51 \%$ respectively, $p<0.05)$, the specific weight of living space equipped with central heating is higher by three times $(53.0 \pm 7.1$ and $16.0 \pm 2.6 \%$ respectively, $p<0.05)$, as well as the average monthly nominal calculated salary of the economic workers is higher by $30 \%$ (18 $456 \pm 753$ and $13848 \pm 189$ rub. respectively, $p<0.05)$.

According to the materials of the state statistical reporting the urban settlements of the territory have higher than in the rural morbidity of children of the age group 0-1 year in total with diseases (227 059 per 100000 of urban population versus 173996,7 per 100000 of rural, $p<0.05$ ); respiratory diseases (indicator per 100000 of population in the cities 101725.7 versus 71247,7 - in the country, $p<0.05$ ).

The number of women delivered the children with the body weight from 1000 to $2500 \mathrm{~g}$ in the cities of the territory by six times exceeds the same in the rural area (6.6 per 1000 of newborns in the cities versus 1 per 1000 of newborns in the villages). Together with it, the children of the age group 0-1 year in the rural area more than two times often compared to the urban suffer from the diseases of blood, bloodforming organs and separate disorders involving the immune mechanisms (17 071.0 per 100000 of children of the age group $0-1$ year in the villages versus 7655.5 per 100000 of children of the age group $0-1$ year in the cities), anemia (16928.6 per 100000 of children of the age group $0-1$ year in the villages versus 7605.6 - in the cities).

The analysis of sanitary and epidemiological factors of living environment for the population of the territory established that in average for the territory the total individual carcinogenic risk of food products exceeds the permissible level $\left(10^{-4}\right)$ by 1.7 and 5.6 times - in the urban and rural settlements respectively. In the cities the highest levels of individual carcinogenic risk of the food products are stipulated by arsenic $\left(1.2 \cdot 10^{-4}\right)$, in the rural settlements - by lead $\left(3.7 \cdot 10^{-4}\right)$ and arsenic $\left(2.5 \cdot 10^{-4}\right)$.

The cities where the level of individual carcinogenic risk stipulated by arsenic contained in the food products exceeds the permissible include - Barnaul $\left(1.9 \cdot 10^{-4}\right)$, Belokurikha $\left(3.1 \cdot 10^{-4}\right)$, and Novoaltaysk $\left(1.5 \cdot 10^{-4}\right)$. The rural settlements with prevalence of individual carcinogenic risk stipulated by the lead of the food products include - Klyuchevskoy $\left(1.5 \cdot 10^{-2}\right)$, Loktevsky $\left(1.3 \cdot 10^{-4}\right)$, Nemetsky natsionalny $\left(1.8 \cdot 10^{-}\right.$ 
$\left.{ }^{4}\right)$, Petropavlovsky $\left(1.1 \cdot 10^{-4}\right)$, Tretyakovsky $\left(1.1 \cdot 10^{-}\right.$ $\left.{ }^{4}\right)$, and Khabarsky $\left(2,4 \cdot 10^{-4}\right)$ administrative districts.

The individual carcinogenic risk stipulated by benzapyrene contained in the food products $\left(1.0 \cdot 10^{-7}\right)$ is more apparent in the cities than in villages though at the negligibly low level. The individual carcinogenic risk of food products in the rural settlements than in the cities is stipulated by hexachlorobenzene $\left(3.7 \cdot 10^{-5}\right.$ at $9.8 \cdot 10^{-7}$ in the cities, $p<0.05)$, DDT $\left(2.6 \cdot 10^{-5}\right.$ at $3.8 \cdot 10^{-6}$ in the cities, $p<0.05)$ and $2,4-\mathrm{D}\left(1.1 \cdot 10^{-6}\right.$ at $3.5 \cdot 10^{-8}$ in the cities, $p<0.05)$.

The number of expected additional cases of cancer among the urban and rural population per year is 23 . Among them 16 cases are for 984100 persons of rural population (1.59 per 100 thous. of population) an 7 cases per $1 \mathrm{mln} .342 .1$ thous. of urban population ( 0.57 per 100 thous. of population).

The analysis of the total indexes of hazard for the chemical substances of food products demonstrated that the exceeding of permissible level (1.0) is observed for arsenic (1.7), lead (3.2), nitrates (1.3), hydroxymethyl furfural (9.8) and histamine (4 600.7).

The contribution of food products to the increased level of the arsenic hazard index is: dairy products $-23 \%$, bakery products $-22 \%$ and canned fish and fish products $-17 \%$. The contribution to the total index of the lead hazard in the food products is mainly $82 \%$ which is stipulated by its content in the vegetable oil. The leading contribution to the index of hazard for nitrates is made by vegetables $(63 \%)$ and potato $(32 \%)$.

Among 14 critical organs and systems of body for which the toxic substances contained in the territorial food products represent the risk of harmful impact only 1 critical system (central nervous system) is exposed to the increased risk in the inhabitants of urban settlements. In the rural settlements the population is exposed to the increased risk of disorders in the functions of 3 critical body systems - hormonal, central nervous system and blood system. Eventually, the conventional body damage hazard indicator in the form of the sum of hazard indexes of the separate critical organs and systems for the urban inhabitants was 7.9, and for rural settlements -9.5 . Therefore, the inhabitants of rural settlements are exposed to higher non-carcinogenic risk (by 20\%) stipulated by the toxic substances contained in the food products.

The results of calculation of the indexes of hazard from the chronic action for the toxic sub- stances of atmospheric air demonstrated that for none of the controlled substances the average indexes of hazard from the chronic action under the several observation posts for population cluster exceeded 1, both for urban and rural settlements.

The highest levels of the average coefficient of hazard for the chronic action of the toxic substances of atmospheric air in the urban settlements were observed for copper oxide (0.998) and cadmium oxide (0.791) in Zmeinogorsk as well as for divanadium pentoxide (0.727) in Barnaul. In the rural settlements the highest levels of index of hazard for the chronic action of chemical substances were also observed for copper oxide (0.998) and cadmium oxide (0.791-0.0801) in the settlements of Zmeinogorsky, Loktevsky and Tretyakovsky administrative districts.

The analysis of the average annual levels of carcinogenic risk of atmospheric air in the urban and rural settlements of the territory demonstrated that in average the urban and rural settlements have the increased level of risk (more than $10^{-4}$ ) which exceeds the accepted level of maximum permissible concentration by 3.3 times in the cities and by 2.2 times in the rural settlements. Eventually, the average level of chronic inhalation risk is $2.9 \cdot 10^{-4}$.

The highest level of chronic inhalation carcinogenic risk is observed in Kamen-na-Obi $\left(1.5 \cdot 10^{-3}\right)$, in Talmensky administrative district $\left(4.8 \cdot 10^{-4}\right)$. The following prevails in the list of carcinogenic substances of atmospheric air under the value of total chronic inhalation carcinogenic risk to the health of population at the territory:

- in the urban settlements - black carbon (Aleysk, Slavgorod - $100 \%$, Biysk - $78.1 \%$, Rubtsovsk - $62.4 \%$ ), formaldehyde (Zarinsk - 100 $\%$, Barnaul - $55.6 \%$,), benzene (Kamen-na-Obi $66.6 \%$ ), toluene (Novoaltaysk - $68.7 \%$ ), cadmium oxide (Zmeinogorsk - $62 \%$ );

- in the rural settlements - black carbon (Krutikhinsky, Pavlosky districts - $100 \%$ ), formaldehyde (Talmensky - 64.6\%, Rubtsovsky administrative districts - $54.2 \%$ ), cadmium oxide (Loktevsky - $94.8 \%$, Zmeinogorsky - $63.3 \%$, Tretyakovsky administrative districts $-62.3 \%$ ).

The indexes of hazard for the chemical substances of drinking water from the centralized domestic and drinking water supply systems in the urban and rural settlements characterize the drinking water as non-hazardous at the significant part of the main territory. The index of hazard for the chemical substances of drinking water in the urban settlements both under the average value and under the maximum level does not exceed the permissi- 
ble value 1.0. The index of hazard for the chemical substances of drinking water in the rural settlements under the maximum level exceeds the permissible value 1.0 under the content of nitrates (up to 1.58 ). 24006 persons live at the territory in the conditions of increased non-carcinogenic health risk stipulated by the action of drinking water nitrates, i.e. the blood system disorders (methemoglobinemia) and cardiovascular system.

In none of the studied city and rural settlement the drinking water contains the carcinogens in the concentrations creating the increased levels of carcinogenic risk for population (more than $10^{-}$ $\left.{ }^{4}\right)$.

The results of the correlation analysis revealed that the population health indicators are determined mainly by the demographical structure and level of medical support. Direct connection between the number of medical staff and morbidity of children of the age group $0-1$ year with the digestive system diseases $(r=+0.75)$, percent of teenagers of the age group 15-17 years with visual acuity disorder $(r=+0.87)$, morbidity of children of the age group 0 14 years with urinary stone disease $(r=+0.76)$, between the percent of apartments without the sewage system and mortality of population $(r=+0.66)$, morbidity of adult population of the age group older than 18 years with anemia $(r=+0.64)$; between the expenses for education and morbidity of children of the age group 0-14 years with gastritis, duodenitis $(r=+0.85)$, morbidity of teenagers of the age group $15-17$ years with gastritis, duodenitis $(r=+0.76)$.

Study of relationship between the hygienic parameters of the living environment (atmospheric air, drinking water, climate) and the public health indicators in the urban settlements of the territory revealed that the infant mortality is associated with the total index of hazard in relation to the atmospheric air contamination with substances for which the respiratory organs are the critical organ of harmful action ( $r=+0.83)$. The average level of the total index of hazard in relation to the atmospheric air contamination in the cities of the territory by 2 times exceeds the normative level. Also the high level of relationship of the infant mortality in the urban settlements of the territory is observed with the value of total carcinogenic risk of substances contaminating the atmospheric air (furnace black $r=+0.78$; the sum of carcinogens $r=+0.77$ ). Herewith the value of risk stipulated by them exceeds the permissible level and is $6 \cdot 10^{-4}$ and $16 \cdot 10^{-4}$, respectively.

We established the relationship of morbidity of population between the digestive organs dis- eases and contamination of food products with hexachlorobenzene $(r=+0.99)$ and mercury $(r=+0.92)$. But the level of doses in relation to the intake of these substances to the human body with the food products can be assessed as hazardous (the indexes of hazard are 0.04 and 0.08 , respectively).

The intake of cadmium with the food products to the human body has direct relationship with the morbidity of children of the age group 0-14 years with metabolic activity diseases, adiposis ( $r=+0.74$ ), and herewith the level if the cadmium index of hazard does not exceed $1-0.2$. The relationships between the morbidity of children of the age group 0-14 years with mental aberrations and climatic parameters - average air temperature in January $(r=-0.72)$ and average air temperature for January and July $(r=+0.7)$ are of certain interest.

The condition of health of teenagers of the age group 15-17 years in the urban settlements of the territory is characterized by the direct relationship between the total contamination of atmospheric air with substances for which the respiratory organs are the critical organs of the harmful action and prevalence among the teenagers of the faults in posture $(r=+0.89 ; \mathrm{IH}=2)$, morbidity with bronchial asthma $(r=+0.77 ; \mathrm{IH}=2)$. The prevalence of the faults in posture among the teenagers is also directly associated with intake of lead compounds with food products to human body $(r=+0.73$ : $\mathrm{IH}=1.2$ ), and metabolic activity disorders, adiposis - with intake of arsenic with food products $(r=+0.75 ; \mathrm{IH}=0.69)$.

The inverse relationship between the morbidity of adult population with chronic bronchitis and intake with drinking water of the sum of chemical substances $(r=-0.93 ; \mathrm{IH}=1.4)$ is detected. Also the inverse dependence is established between the morbidity of adult population of the age group older than 18 years with the metabolic activity diseases, adiposis and the average temperature in July $(r=-0.65)$.

The relationship between the content of toxic substances in the food products and morbidity of adult urban population of the territory is of special interest. The direct relationship is established only for lead $(r=+0.66 ; \mathrm{IH}=1.2)$ and the metabolic activity disorders and adiposis.

For the rural population the dependences between the indicators of living environment and the health of population are characterized by inverse relationship between the number of doctors and the morbidity of adult population older than 18 years with insulin dependent diabetes mellitus $(r=-0.34)$ 
and, on the contrary, by the direct relationship between the morbidity of adult population of the age group older than 18 years with drug addiction $(r=+0.34)$. The inverse dependence of morbidity with diabetes mellitus on the number of doctors characterizes the effectiveness of preventive work in relation to this pathology and the ability to prevent effectively its manifesting forms and affect directly the risk factors.

The equipping of apartments with central heating favorably affects the morbidity of children of the age group 0-1 year with congenital abnormalities $(r=-0.33)$, the total morbidity of children of the age group $0-1$ year $(r=-0.36)$ and even the mortality of population $(r=-0.34)$.

The integral indicator of economic activity at the territory "average per capita income of population" in the country has the inverse relationship with morbidity with alcoholism $(r=-0.31)$, urinary stone disease $(r=-0.34)$, total morbidity $(r=-0.35)$ and direct relationship with the metabolic activity disorder and adiposis of adults $(r=+0.53)$.

For the rural settlements the relationship between the condition of health and hygienic factors of living environment is expressed in that for the children of the age group 0-1 year we established the inverse relationship between the morbidity with digestive system diseases and intake to the body of arsenic with food products $(r=-0.39, \mathrm{IH}=2.6)$. For the rural children of the age group 0-14 years we observed the relationship between the total morbidity and intake of hexachlorocyclobenzene with food products $(r=+0.66, \mathrm{IH}=1.1)$.

For adult rural population of the territory we established the inverse relationships between the morbidity of non insulin dependent diabetes mellitus and intake to the human body with food products of hexachlorocyclobenzene $(r=-0.74$, $\mathrm{IH}=1.1)$, morbidity with peptic ulcer and intake to the human body with food products of arsenic ( $r=$ $-0.41 ; \mathrm{IH}=2.6$ ).

The relationship between the climatic conditions and the morbidity of adult rural population of the territory is characterized by the direct dependence of morbidity with bronchial asthma and the average temperature of January $(r=+0.27)$, as well as the inverse dependence of alcoholism prevalence and air temperature $(\mathrm{r}=-0.31$ and $r=-0.28$, respectively).

Therefore, the conducted analysis of the social and sanitary-epidemiological living conditions for population of the territory revealed that the social and economic conditions of life in the urban settlements are characterized by higher levels of the economic activity of population, better availability of medical assistance, better sanitary and domestic living conditions (water supply, sewage system, heating) compared to rural; the contamination of atmospheric air at the urban and rural settlements of the territory is characterized by the increased level of non-carcinogenic risk stipulated by the divanadium pentoxide, arsenic, formaldehyde, as well as the copper and cadmium oxides at the production sites mining and ore industry; increased level of carcinogenic risk stipulated by the emission to atmosphere of furnace black (black carbon), formaldehyde; the leading place in the structure of carcinogenic risk stipulated by the food products is occupied by arsenic for urban inhabitants (vegetables, bakery products) and lead, arsenic - for rural inhabitants (potato, milk, meat, bakery products). The central nervous system, endocrine and blood systems are the critical organs and systems when exposed to the toxic substances of the food products; the condition of health of population for all the age groups of urban inhabitants is characterized by more expressed compared to the rural inhabitants relationship with the level of hazard from the contaminations of atmospheric air, drinking water and food products.

\section{References}

1. Rahmanin Ju.L., Ivanov S.I., Novikov S.M. i soavt. Aktual'nye problemy kompleksnoj gigienicheskoj harakte-ristiki faktorov gorodskoj sredy i ih vozdejstvija na zdorov'e [Acute problems of the complex hygienic characteristic of the factors of urban environment and their impact on the health of population]. Gigiena $i$ sanitarija, 2007, no. 5, pp. 5-6.

2. Saldan I.P., Goncharenko A.G., Ushakov A.A. i dr.Invalidnost' detej Altajskogo kraja: rasprostranennost', struktura, dina-mika, faktory riska (na osnove social'no-gigienicheskogo pasporta za 1999-2011 gg.: Monografija [Disability of children of the Altai Territory: prevalence, structure, dynamics, risk factors (in terms of the hygienic passport 1999-2011)]. Barnaul: Izd-vo AltGTU, 2012. 234 p. 
3. Kreymer M.A. Nekotorye rezul'taty social'no-gigienicheskogo monitoringa i napravlenija po ego sovershenstvovaniju [Some results of the social and hygienic monitoring and ways of its improvement]. Gigiena $i$ sanitarija, 2007, no. 1, pp. 80-82.

4. Onishhenko G.G. Ocenka riska vlijanija faktorov okruzhajushhej sredy na zdoro-v'e v sisteme social'nogigienicheskogo monitoringa [Risk assessment of the impact of environmental factors on health in the system of social and hygienic monitoring]. Gigiena i sanitarija, 2002, no. 6, pp. 3-5.

5. O sostojanii sanitarno-jepidemiologicheskogo blagopoluchija naselenija v Al-tajskom krae v 2013 godu: Gosudarstvennyj doklad [On the state of sanitary and epidemiological wellbeing of the population in the Altai Territory in 2013: State Report]. Upravlenie Federal'noj sluzh-by po nadzoru v sfere zashhity prav potrebitelej i blagopoluchija cheloveka po Altaj-skomu kraju, 2014. 194 p.

6. Saldan I.P., Ushakov A.A., Karpova T.N., Katunina A.S. Social'no-gigienicheskij monitoring. Invalidnost' detej: vedenie monitoringa v Altajskom krae (obzor za 1999-2013 gg.). [Social and hygienic monitoring. Disability of children: monitoring in the Altai Territory (review 1999-2013)]. Informacionnyj sbornik statisticheskih $i$ analiticheskih materialov. Barnaul: AZBUKA, 2014. 124 p.

7. Saldan I.P., Ushakov A.A., Karpova T.N., Katunina A.S. Social'no-gigienicheskij pasport Altajskogo kraja po vrozhdennym porokam razvitija u detej (ploda) (na osnove dannyh za 1999-2013 gg.) [Social and hygienic passport of the Altai Territory according to the congenital defects of children (fetus) (on the basis of data from 19992013)]. Informacionnyj sbornik statisticheskih i analiticheskih materialov. Barnaul: AZBUKA, 2014. 131 p. 